\title{
Comparative study: normotensive and preeclampsia mother presenting with imminent symptoms of eclampsia in third trimester of pregnancy
}

\author{
Raji C., Suba S.*
}

Department of Obstetrics and Gynecology, Government Theni Medical College, Theni, Tamil Nadu, India

Received: 05 February 2020

Accepted: 02 March 2020

\section{*Correspondence:}

Dr. Suba S.,

E-mail: rajidr_2003@yahoo.co.in

Copyright: (C) the author(s), publisher and licensee Medip Academy. This is an open-access article distributed under the terms of the Creative Commons Attribution Non-Commercial License, which permits unrestricted non-commercial use, distribution, and reproduction in any medium, provided the original work is properly cited.

\begin{abstract}
Background: This prospective study compares the maternal and fetal outcome in normotensive and preeclampsia mother presenting with imminent symptoms of eclampsia in third trimester. This prospective study was conducted in the department of obstetrics and gynaecology, Government Theni Medical College, Tamil Nadu, India in 2019.

Methods: A total 100 antenatal mothers were selected for the study. Group A - 50 known case of preeclampsia presented with imminent symptoms. Group B-50 previously normotensive patients present with imminent symptoms of eclampsia. Maternal and fetal outcome were analysed.

Results: Incidence of eclampsia - 0.1\%, HELLP syndrome - $0.04 \%$, pulmonary edema - 0.06\%, PRES - $0.07 \%$, abruptio placenta - $0.14 \%$ and maternal death in Group A was 2\% and in Group B was 8\%. Maternal complications are more in normotensive women (46\%) presented with imminent symptoms than in preeclampsia women $(26 \%)$ with imminent symptoms. Incidence of IUGR in Group A was 46\%, whereas in Group B $12 \%$. Incidence of preterm babies in Group A was 18\%, whereas in Group B was $42 \%$. Perinatal death incidence was $2.2 \%$ in imminent eclampsia.

Conclusions: Because known preeclampsia patients were aware of imminent symptoms and presented early to hospital. Early identification and treatment of this dreadful outcome at the imminent state itself can reduce the complications. In current status on preventive aspect of eclampsia, atypical presentation should also be considered for which new screening and diagnostic tools has to be developed.
\end{abstract}

Keywords: Fetomaternal outcome, Non severe preeclampsia, Severe preeclampsia

\section{INTRODUCTION}

Preeclampsia is a pregnancy specific multisystem disease diagnosed by the characteristic appearance of gestational hypertension and significant proteinuria from the second half of pregnancy in a previously normotensive and a proteinuria woman. ${ }^{1}$

Globally, pre-eclampsia is said to complicate $2-10 \%$ of pregnancies. ${ }^{2}$ Although, the outcome is often good, preeclampsia often is associated with increased maternal and perinatal morbidity and mortality. ${ }^{3}$ Severe pre-eclampsia with prodromal symptoms is called Imminent eclampsia. The prodromal symptoms are headache, epigastric pain, nausea, vomiting, oliguria and blurring of vision. Eclampsia can occur any period of pregnancy antepartum, intrapartum and postpartum. Overall, 10\%$15 \%$ of maternal deaths are directly associated with preeclampsia and eclampsia. ${ }^{4,5}$

The aetiology of preeclampsia is largely unknown and had been referred to as the "disease of theories". ${ }^{6-8}$ Central to its pathophysiology is the abnormal placentation, release of soluble factors from the ischaemic placenta into maternal plasma plays a central role in endothelial dysfunction which is the most prominent feature of this disease. ${ }^{9,10}$ The disease can occur in the absence of fetal tissue and the clinical 
manifestations of the disease begin to resolve following delivery of the placenta. ${ }^{11,12}$ It is more common in the first pregnancy, in women with previous history of preeclampsia, gestational diabetes, multiple gestation, connective tissue diseases, and extremes of maternal age. ${ }^{13}$

Management principles continuously balance the risks against the benefits of induced preterm delivery and maternal and fetal complications. ${ }^{14}$ Mild preeclampsia may be managed on an outpatient basis. Antihypertensive may be commenced at systolic blood pressure of 150 mmHg. ${ }^{15}$ Severe preeclampsia involves stabilization and delivery by the most expeditious route. Resuscitation and stabilization of patients with severe preeclampsia may involve administration of magnesium sulphate to prevent fits, anti-hypertensives to control blood pressure, restriction of fluid intake and delivery. ${ }^{15}$

It is estimated that about 63,000 maternal deaths occur from hypertensive diseases in pregnancy each year with more than $98 \%$ of these deaths occurring in developing countries. ${ }^{16}$ These maternal deaths often result from complications associated with pre-eclampsia such as eclampsia, HELLP syndrome; (haemolysis, elevated liver enzymes and low platelet) and pulmonary edema. Others include stroke, abruptio placentae and disseminated intravascular coagulopathy. ${ }^{17,18}$ Adverse perinatal outcomes associated with this disorder of pregnancy include intrauterine growth restriction, preterm delivery, admission into new-born intensive unit, and perinatal deaths. ${ }^{19,20}$ Hence intensive surveillance is often required for optimal maternal and perinatal outcome. ${ }^{21,22}$ The rate of progression and the occurrence of catastrophic complications are often difficult to predict. ${ }^{23}$

\section{Objectives}

- To analyze the determinants of imminent eclampsia.

- To analyze prevalence of imminent eclampsia and complications.

- To analyze the maternal and perinatal outcome in preeclampsia and previously normotensive presents with imminent eclampsia.

- To analyze the complications due to atypical presentation and compare with women with imminent symptoms.

- To discuss the timely measures to prevent eclampsia and its complications.

\section{METHODS}

Prospective study was conducted in preeclampsia and normotensive mother admitted with imminent symptoms and comparison of fetomaternal outcome.

A total 100 antenatal mothers were selected for this study.
Group A - 50 known case of preeclampsia presented with imminent symptoms of eclampsia.

Group B - 50 previously normotensive patients presented with imminent symptoms of eclampsia.

This study conducted at department of obstetrics and gynecology. Government Theni Medical College.

One-year duration of the study (2019). Informed consent obtained from all patients.

\section{Inclusion criteria}

- All pregnant women with imminent symptoms

- All pregnant women with antepartum eclampsia preceded with imminent symptoms.

\section{Exclusion criteria}

- Antenatal patient presented as eclampsia or post ictal phase in admission- without prodromal symptoms

- Epilepsy

- Trauma (head injury)

- Metabolic disorder (anaemia, electrolyte imbalance, hepatic / renal failure, hypoglycemia)

- Poisoning (strychnine, CNS stimulant)

- Infection (meningitis, encephalitis, cerebral malaria)

- Functional.

History was elicited from patient and if patient is unconscious or in postictal state, history was elicited from attender. A detailed history of the patient regarding age, parity, socio-economic status, booking status, gestational age, prodromal symptoms, details about imminent symptoms, convulsions, referral and treatment (including $\mathrm{MgSO}_{4}$ administration) at referral centre were noted down. Details about previous obstetric history were recorded.

\section{Emergency care}

When the patient with convulsion was received, Patient nursed in left lateral position and suction of secretions done to prevent aspiration. The bedside rails were elevated to prevent maternal injury. Mouth gag was placed to prevent tongue bite. Oxygen by mask is given at rate of 8-10 liter/minute. IV line started.

\section{Clinical evaluation}

Detailed general examination and obstetric examination were done. In general examination conscious level, anaemia, pedal edema, facial puffiness, jaundice, BMI, blood pressure, pulse rate, respiratory rate, temperature, thyroid, fundus and nature of fits were recorded. RS, CVS, CNS were examined. 
Loading dose $\mathrm{MgSO}_{4}$ given as prophylactically in all patients with imminent symptoms and therapeutically in eclampsia. $\mathrm{MgSO}_{4}$ was given according to Pritchard regimen.

All cases were started on Labetalol $100 \mathrm{mg}$ bd was started and dose adjusted according to BP. If diastolic BP was $>110 \mathrm{mmHg}$. T. Nifedipine $10 \mathrm{mg}$ TDS started. For patient who had uncontrolled BP, IV labetalol was given. Dose of IV labetalol was $20 \mathrm{mg}$ IV bolus given initially. If the blood pressure did not decrease in 10 minutes, additional dose of $40 \mathrm{mg}$, then $80 \mathrm{mg}$ administered every 10 minutes as needed to a maximum of $220 \mathrm{mg}$. For continuous IV administration, one $20 \mathrm{ml}$ vial containing $100 \mathrm{mg}$ Labetalol was added to $400 \mathrm{ml}$ of lactated Ringers solution. The resultant solution had $1 \mathrm{mg} / \mathrm{ml}$, the initial dose was $20 \mathrm{mg} /$ hour. This dose was doubled every 20 minutes up to maximum of $220 \mathrm{mg}$. The therapeutic range is usually between 50 and $200 \mathrm{mg}$. Once the blood pressure reached the desired level, the IV solution was discontinued and the patient was started on oral labetalol, $100-400 \mathrm{mg}$ every 6-12 hours up to maximum of 2400 $\mathrm{mg}$.

\section{Obstetric management}

After stabilizing the patient, mode of delivery was planned according to gestational age, presentation, viability of fetus, cervical scoring and pelvic assessment.

Vaginal delivery was preferred and induction done with $\mathrm{PGE}_{2}$ gel for patient who was not in labour. When patient was in labour, acceleration was done with aminotomy and oxytocin infusion. LSCS was done for maternal, fetal indication and when $\mathrm{PGE}_{2}$ induction failed.

Immediately after delivery of baby, 10 units of oxytocin given intramusucular. The patient was carefully monitored. The patient was observed for 48 hours in eclampsia room. Blood pressure was monitored and antihypertensives continued. $\mathrm{MgSO}_{4}$ was continued $4^{\text {th }}$ hourly till 24 hours after delivery by monitoring patellar reflex, respiratory rate and urine output. After 48hours patient shifted to postnatal or postoperative ward respectively.

\section{Fetal outcome analysis}

Details of baby such as birth weight, maturity, sex and complication like prematurity, IUGR, birth asphyxia and mortality were recorded. Baby was followed up till discharge.

\section{Postpartum care}

Postnatally antihypertensive drugs continued till 12 weeks and slowly tapered when blood pressure returned to normal. While discharge patient was advised for contraception and review after a week. Patient was advised about early booking in next pregnancy.

\section{RESULTS}

\section{Our study results are}

- Total number of deliveries in 2019 in study hospital is 8076

- Incidence of imminent eclampsia - $1.2 \%$

- Incidence of eclampsia - $0.1 \%$

- Incidence of HELLP - $0.04 \%$

- Incidence of pulmonary oedema $-0.06 \%$

- Incidence of PRES - $0.07 \%$

- Incidence of abruption - $0.14 \%$.

In preeclampsia mother, $40 \%$ imminent eclampsia occurred in age $<25$ years. $14 \%$ imminent eclampsia occurred in age $<20$ years. In normotensive mothers, $28 \%$ presented with imminent eclampsia in <20 years. $38 \%$ were in the age group of 20 to 25 years. In both group, commonest age was $<2$. p value $>0.05$, statistically not significant (Table 1).

Table 1: Age distribution.

\begin{tabular}{|lllll|}
\hline Age & Group A preeclampsia & Percentage & Group B normotensive & Percentage \\
\hline$<20$ years & 7 & $14 \%$ & 14 & $28 \%$ \\
\hline $20-25$ years & 20 & $40 \%$ & 19 & $38 \%$ \\
\hline $25-30$ years & 15 & $30 \%$ & 11 & $22 \%$ \\
\hline $30-35$ years & 7 & $14 \%$ & 5 & $10 \%$ \\
\hline$>35$ years & 1 & $2 \%$ & 1 & $2 \%$ \\
\hline Mean \pm SD & $25.42 \pm 4.7$ & & $24.3 \pm 6.0$ & \\
\hline p value: $p>0.05$ & & &
\end{tabular}

Regarding parity, 32 out 50 mothers were primigravida in Group B and 27 out 50 were primigravida in Group A. In both groups, it is common in primigravida. $\mathrm{p}$ value is 0.01 , statistically significant (Table 2). 
Imminent eclampsia is common in low socioeconomic class (41 preeclampsia mothers and 42 normotensive mothers). No difference between two groups, $\mathrm{p}$ value > 0.05 , statistically not significant (Table 3 ).

Table 2: Parity.

\begin{tabular}{|llll|}
\hline Parity & Group A preeclampsia & Group B normotensive & p value \\
\hline Primigravida & 27 & 32 & 0.01 \\
\hline Multigravida & 23 & 18 & \\
\hline
\end{tabular}

Table 3: Socio economic class.

\begin{tabular}{|c|c|c|c|}
\hline Class & $\begin{array}{l}\text { Group A } \\
\text { preeclampsia }\end{array}$ & $\begin{array}{l}\text { Group B } \\
\text { normotensive }\end{array}$ & p value \\
\hline I & - & - & \multirow{5}{*}{$\begin{array}{l}p>0.05 \\
(0.3)\end{array}$} \\
\hline II & - & - & \\
\hline III & 9 & 8 & \\
\hline IV & 20 & 20 & \\
\hline V & 21 & 22 & \\
\hline
\end{tabular}

Regarding booking status, 42 mothers had $>3$ visits in preeclampsia group and 44 in normotensive group (Table 4).
A total $76 \%$ preeclampsia mothers and $74 \%$ normotensive mothers were referred (Table 5). Regarding gestational age, 56\% preeclampsia mothers and 62\% normotensive mothers were in gestational age between $34-37$ weeks. $26 \%$ of preeclampsia mothers and $10 \%$ of normotensive mothers were in gestational age > 37 weeks. $\mathrm{p}$ value is $0.3 \%$ which is not significant (Table 6).

Table 4: Booking status.

\begin{tabular}{|lll|}
\hline Booked & $\begin{array}{l}\text { Group A } \\
\text { preeclampsia }\end{array}$ & $\begin{array}{l}\text { Group B } \\
\text { normotensive }\end{array}$ \\
\hline$<3$ visits & 8 & 6 \\
\hline$>3$ visits & 42 & 44 \\
\hline
\end{tabular}

Table 5: Referral status.

\begin{tabular}{|lllll|}
\hline Referral & Group A preeclampsia & Percentage & Group B normotensive & Percentage \\
\hline From PHC /GH & 38 & $76 \%$ & 37 & $74 \%$ \\
\hline Self & 9 & $18 \%$ & 8 & $16 \%$ \\
\hline In patient & 3 & $6 \%$ & 5 & $10 \%$ \\
\hline
\end{tabular}

Table 6: Gestational age at presentation.

\begin{tabular}{|lllll|}
\hline Gestational age & Group A preeclampsia & Percentage & Group B normotensive & Percentage \\
\hline 28-34 weeks & 9 & $18 \%$ & 9 & $18 \%$ \\
\hline $34-37$ weeks & 28 & $56 \%$ & 31 & $62 \%$ \\
\hline$>37$ weeks & 13 & $26 \%$ & 10 & \\
\hline SD & 0.66 & & 0.63 & \\
\hline Mean & 2 & & & \\
\hline p value & & 0.3 & & \\
\hline
\end{tabular}

Table 7: Prodromal symptoms.

\begin{tabular}{|lllll|}
\hline Prodromal symptoms & Group A preeclampsia & Percentage & Group B normotensive & Percentage \\
\hline Headache & 34 & $68 \%$ & 35 & $70 \%$ \\
\hline Vomiting/epigastric pain & 13 & $26 \%$ & 13 & $26 \%$ \\
\hline Blurring of vision & 2 & $4 \%$ & 2 & $4 \%$ \\
\hline Oliguria & 1 & $2 \%$ & - & \\
\hline
\end{tabular}

$\mathrm{p}$ value $=0.04$.

Regarding presenting symptoms, $68 \%$ preeclampsia mothers and $70 \%$ normotensive mothers had headache.
$26 \%$ mothers in both groups had vomiting and epigastric pain which is significant, $p$ value $<0.05$ (Table 7). In this 
study, 28 preeclampsia mothers and 22 normotensive mothers had risk factors. Previous history of preeclampsia was the major risk factor in both groups. ${ }^{13}$ Preeclampsia mothers and 8 normotensive mothers had previous history of preeclampsia (Table 8).

In relation to BMI, $52 \%$ of mothers in preeclampsia and $28 \%$ of normotensive mothers were obese $\mathrm{p}$ value was $<0.05$, statistically significant (Table 9).

Table 8: Risk factors.

\begin{tabular}{|l|ll|}
\hline Risk factors & $\begin{array}{l}\text { Group A } \\
\text { preeclampsia }\end{array}$ & $\begin{array}{l}\text { Group B } \\
\text { normotensive }\end{array}$ \\
\hline $\begin{array}{l}\text { Previous history of } \\
\text { preeclampsia }\end{array}$ & 13 & 8 \\
\hline Twins & 1 & 4 \\
\hline Anaemia & 4 & 6 \\
\hline Infertility treated & 4 & 2 \\
\hline $\begin{array}{l}\text { Gestational diabetes } \\
\text { mellitus }\end{array}$ & 4 & - \\
\hline Hypothyroid & 2 & 2 \\
\hline Total & $\mathbf{2 8}$ & $\mathbf{2 2}$ \\
\hline
\end{tabular}

In comparison of blood pressure, 26 mothers in preeclampsia group and 24 mothers in normotensive mothers had BP $<160 / 110 \mathrm{mmHg}$. Mean systolic BP $(148.8 \pm 11.5)$ in preeclampsia and $158.6 \pm 17.72$ in normotensive mothers and mean diastolic BP 98.6 \pm 7.5 in preeclampsia and $102.2 \pm 8.15$ in normotensive mothers $\mathrm{p}$ value was 0.01 , statistically significant (Table 10).

Regarding pedal edema, in preeclampsia group, 28 mothers had grade II Pedal edema. Whereas, in normotensive mother 36 had grade I pedal edema. $p$ value was 0.02 (Table 11).

Table 9: Body mass index.

\begin{tabular}{|lll|}
\hline BMI & $\begin{array}{l}\text { Group A } \\
\text { preeclampsia }\end{array}$ & $\begin{array}{l}\text { Group B } \\
\text { normotensive }\end{array}$ \\
\hline $\begin{array}{l}\text { Underweight } \\
(<18.5)\end{array}$ & $0(0 \%)$ & $1(2 \%)$ \\
\hline Normal $(18.5-24.9)$ & $4(8 \%)$ & $12(24 \%)$ \\
\hline $\begin{array}{l}\text { Overweight } \\
(25-29.9)\end{array}$ & $20(40 \%)$ & $23(46 \%)$ \\
\hline Obese $(>30)$ & $26(52 \%)$ & $14(28 \%)$ \\
\hline p value $=0.006$. & & \\
\hline
\end{tabular}

Table 10: Blood pressure.

\begin{tabular}{|c|c|c|c|}
\hline \multicolumn{2}{|c|}{ Blood pressure } & Group A preeclampsia & Group B normotensive \\
\hline \multicolumn{2}{|c|}{$<140 / 90$} & 6 & 3 \\
\hline \multicolumn{2}{|l|}{$<160 / 110$} & 29 & 26 \\
\hline \multicolumn{2}{|l|}{$>160 / 110$} & 12 & 15 \\
\hline \multicolumn{2}{|l|}{$>190 / 110$} & 3 & 6 \\
\hline Variable & Group A preeclampsia & Group B normotensive & p value \\
\hline SBP & $148.8 \pm 11.5$ & $158.6 \pm 17.72$ & 0.01 \\
\hline DBP & $98.6 \pm 7.5$ & $102.2 \pm 8.15$ & 0.01 \\
\hline
\end{tabular}

Table 11: Pedal edema.

\begin{tabular}{|lll|}
\hline Grading & $\begin{array}{l}\text { Group A } \\
\text { preeclampsia }\end{array}$ & $\begin{array}{l}\text { Group B } \\
\text { normotensive }\end{array}$ \\
\hline I & 18 & 36 \\
\hline II & 28 & 12 \\
\hline III & 4 & 2 \\
\hline IV & - & - \\
\hline
\end{tabular}

Table 12: Urine albumin - dipstick.

\begin{tabular}{|c|c|c|c|}
\hline $\begin{array}{l}\text { Urine } \\
\text { albumin }\end{array}$ & $\begin{array}{l}\text { Group A } \\
\text { preeclampsia }\end{array}$ & $\begin{array}{l}\text { Group B } \\
\text { normotensive }\end{array}$ & p value \\
\hline Nil & - & 4 & \multirow{5}{*}{0.28} \\
\hline $1+$ & 24 & 24 & \\
\hline $2+$ & 14 & 15 & \\
\hline $3+$ & 9 & 5 & \\
\hline $4+$ & 3 & 2 & \\
\hline
\end{tabular}

In relation to urine albumin, 24 mothers had $1+$ urine albumin in both groups. 14 and 15 mothers had $2+$ urine albumin in preeclampsia and normotensive mothers respectively. $\mathrm{p}$ value is 0.2 which was statistically not significant (Table 12).

All women received $\mathrm{MgSO}_{4}$ either in referral unit or in study hospital (Table 13).

Table 13: Administration of magnesium sulphate.

\begin{tabular}{|lll|}
\hline $\mathrm{MgSO}_{4}$ & $\begin{array}{l}\text { Group A } \\
\text { preeclampsia }\end{array}$ & $\begin{array}{l}\text { Group B } \\
\text { normotensive }\end{array}$ \\
\hline Before admission & 17 & 19 \\
\hline After admission & 33 & 31 \\
\hline
\end{tabular}

LSCS plays major role in Imminent eclampsia. In order to prevent complications, termination of pregnancy was 
done by LSCS. p value 0.08 , statistically not significant. $74 \%$ in Group B took for emergency LSCS directly in view of unfavourable cervix and maternal complications with poor bishop score. $60 \%$ patients in Group A undergone LSCS in view of unfavourable cervix before induction in view of maternal condition. In Group A $26 \%$ and in Group B 14\% of patients indication was due to failure to progress (Table 14).

Regarding induction delivery interval, $82 \%$ of induced cases of Group B and 40\% in Group A delivered in 12 hours. $p$ value $<0.01$, statistically significant (Table 15).

Table 14: Mode of delivery.

\begin{tabular}{|lll|}
\hline Mode of delivery & Group A preeclampsia & Group B normotensive \\
\hline Labour natural & 7 & 6 \\
\hline LSCS & 43 & 44 \\
\hline Unfavourable cervix and maternal complications & $60 \%$ & $74 \%$ \\
\hline Failure to progress & $26 \%$ & $14 \%$ \\
\hline Cephalopelvic disproportion & $10 \%$ & $10 \%$ \\
\hline Others & $4 \%$ & $2 \%$ \\
\hline
\end{tabular}

$\mathrm{p}$ value $=0.08$ (not significant) .

Table 15: Induction delivery interval in induced cases.

\begin{tabular}{|lll|}
\hline Induction- delivery interval & Group A preeclampsia & Group B normotensive \\
\hline No. of induced cases & 20 & 11 \\
\hline$<6$ hours & - & $7(64 \%)$ \\
\hline $6-12$ hours & $8(40 \%)$ & $2(18 \%)$ \\
\hline $12-24$ hours & $12(60 \%)$ & $2(18 \%)$ \\
\hline
\end{tabular}

$\mathrm{p}$ value $=0.08$ (not significant).

Table 16: Admission delivery interval.

\begin{tabular}{|lll|}
\hline Admission delivery interval & Group A preeclampsia & Group B normotensive \\
\hline$<6$ hours & $2(4 \%)$ & $33(66 \%)$ \\
\hline $6-12$ hours & $25(50 \%)$ & $5(10 \%)$ \\
\hline $12-24$ hours & $10(20 \%)$ & $5(10 \%)$ \\
\hline $24-48$ hours & $8(16 \%)$ & $1(2 \%)$ \\
\hline$>2$ days & $5(10 \%)$ & $6(12 \%)$ \\
\hline
\end{tabular}

Table 17: Maternal complications.

\begin{tabular}{|lll|}
\hline Complications & Group A preeclampsia & Group B normotensive \\
\hline Antepartum eclampsia & $3(6 \%)$ & $4(8 \%)$ \\
\hline Postpartum eclampsia & - & $2(4 \%)$ \\
\hline Posterior reversible encephalopathy syndrome & $1(2 \%)$ & $5(10 \%)$ \\
\hline HELLP* syndrome & $3(6 \%)$ & $1(2 \%)$ \\
\hline Pulmonary edema & $1(2 \%)$ & $4(8 \%)$ \\
\hline Abruptio placenta & $5(10 \%)$ & $7(14 \%)$ \\
\hline Total & $\mathbf{1 3 ( 2 6 \% )}$ & $\mathbf{3 3 ( 4 6 \% )}$ \\
\hline
\end{tabular}

*HELLP: Haemolysis, elevated liver enzymes, low platelet count.

Table 18: Maternal mortality.

\begin{tabular}{|llll|}
\hline Cause & $\begin{array}{l}\text { Group A } \\
\text { preeclampsia }\end{array}$ & $\begin{array}{l}\text { Group B } \\
\text { normotensive }\end{array}$ & $\%$ \\
\hline $\begin{array}{l}\text { Pulmonary } \\
\text { edema }\end{array}$ & - & 4 & $80 \%$ \\
\hline HELLP & - & 1 & $20 \%$ \\
\hline
\end{tabular}

A total $76 \%$ cases were delivered within 12 hours in Group B in view of maternal and fetal condition, whereas $54 \%$ cases in Group A were delivered within 12 hours. In Group B the incidence of AP eclampsia, pulmonary edema, abruption was high, hence emergency caesarean was done in view of maternal condition. Therefore, 
admission delivery interval was less in Group B when compared to Group A (Table 16).

Table 19: Neonatal outcome.

\begin{tabular}{|lll|}
\hline Outcome & $\begin{array}{l}\text { Group A } \\
\text { preeclampsia }\end{array}$ & $\begin{array}{l}\text { Group B } \\
\text { normotensive }\end{array}$ \\
\hline Alive & 38 & 37 \\
\hline Stillbirth & 1 & 1 \\
\hline IUD & 3 & 2 \\
\hline Neonatal death & 8 & 10 \\
\hline
\end{tabular}

$\mathrm{p}$ value $=0.4$.

Maternal complications are more in normotensive women (46\%) presented with imminent symptoms than in preeclampsia women (26\%) with imminent symptoms (Table 17).

Maternal mortality incidence was seen in Group B patients. $80 \%$ death occurred due to pulmonary edema. $20 \%$ due to HELLP (Table 18).

Table 20: Neonatal birth weight.

\begin{tabular}{|lll|}
\hline Birth weight & $\begin{array}{l}\text { Group A } \\
\text { preeclampsia }\end{array}$ & $\begin{array}{l}\text { Group B } \\
\text { normotensive }\end{array}$ \\
\hline$<1.5 \mathrm{~kg}$ & 10 & 9 \\
\hline $1.5-2 \mathrm{~kg}$ & 18 & 9 \\
\hline $2-2.5 \mathrm{~kg}$ & 10 & 12 \\
\hline$>2.5 \mathrm{~kg}$ & 12 & 20 \\
\hline
\end{tabular}

$\mathrm{p}$ value $=0.6$, (not significance $)$.

Incidence of perinatal mortality was $2.2 \%$. In Group B, the main reason was due to low birth weight and respiratory distress, 4 cases in Group B were due to asphyxia (maternal complication). In Group A perinatal mortality was due to IUGR, LBW and sepsis. p value $>0.05$, statistically not significant (Table 19). A total $40 \%$ Group B have good neonatal outcome with birth weight $>2.5 \mathrm{~kg}$. But in preeclampsia group only $20 \%$ had weight $>2.5 \mathrm{~kg}$ (Table 20).

Table 21: Neonatal complications.

\begin{tabular}{|l|ll|}
\hline Complications & $\begin{array}{l}\text { Group A } \\
\text { preeclampsia }\end{array}$ & $\begin{array}{l}\text { Group B } \\
\text { normotensive }\end{array}$ \\
\hline Low birth weight & 9 & 21 \\
\hline IUGR & 23 & 6 \\
\hline
\end{tabular}

$\mathrm{p}$ value 0.004 (significant).

Incidence of IUGR in Group A was $46 \%, 12 \%$ in Group B. Incidence of preterm babies in Group A was $18 \%$, $42 \%$ in Group B. p value 0.004 , statistically significant (Table 21).

\section{DISCUSSION}

Incidence of eclampsia in this study was $0.1 \%$ which was presented with preceding imminent symptoms. Pradeep
MR et al, in their study states that in developing countries incidence of eclampsia varies between 1 in 100 to 1 in 1700 pregnancies. $^{24}$ Bhalerao SA et al, in their study states that incidence of eclampsia in India was 0.94 to $1.8 \%$ and incidence in their study was $0.1 \% .^{25}$

\section{Type of eclampsia}

Antepartum eclampsia in this study was $77.7 \%$, indicating antepartum eclampsia was more common than intrapartum and postpartum eclampsia (22.3\%). Which was comparable to $86.95 \%$ antepartum eclampsia in study by Manjusha $\mathrm{S}$ et al and $45 \%$ antepartum eclampsia in study by Knight $\mathrm{M}$ et al. ${ }^{26,27}$

\section{Age}

A total $60 \%$ of imminent eclampsia were occurred in age $<25$ years in both groups which was comparable to 19-24 years in Pradeep MR et al, and 21-25 years in Manjusha S et al study. ${ }^{24,26}$

\section{Socio-economic status}

In this study imminent eclampsia were common in class $\mathrm{V}$ and IV which is $43 \%$ and $40 \%$ respectively which is comparable to $90 \%$ in study by Pradeep MR et al. ${ }^{26}$

\section{Booking status}

In this study almost all cases of imminent eclampsia were booked. Whereas the study of Sunitha $\mathrm{TH}$ et al, and Pradeep MR et al, they described that $95 \%$ and $88 \%$ of eclamptic cases were unbooked respectively. ${ }^{24,28}$

\section{Parity}

In this study $59 \%$ of imminent eclampsia cases were primigravida and $41 \%$ were multigravida. ${ }^{32}$ Out of 50 cases were primi in Group B, 27 out of 50 cases were primi in Group A which is comparable to $56 \%$ in primigravida in study of Manjusha $\mathrm{S}$ et al, and $79 \%$ in the study of Sunita TH et al. ${ }^{26,28}$

\section{Gestational age}

In this study, $56 \%$ of patients in Group A and $62 \%$ of patients in Group B were in the gestational age of 34 to 37 weeks. $26 \%$ of patients in Group A and 10\% of patients in Group B were in gestational age > 37 weeks which is comparable to study done by Pradeep MR et al, in which $94 \%$ eclampsia occurred in third trimester of which $42 \%$ were term patients. ${ }^{24}$

\section{Prodromal symptoms}

In this study, 68\% in Group A had headache, whereas $70 \%$ had headache in Group B. $4 \%$ of cases in Group A had oliguria. Incidence of vomiting and blurring of vision were equal in both groups. It is comparable to $71 \%$ 
prodromal symptoms in study of Kane SC et al, $80 \%$ in study by Walker JJ et al. ${ }^{29,30}$

\section{$\mathrm{BP}$ at the time of admission}

In this study $42 \%$ patients Group A presented with BP > $160 / 110 \mathrm{mmHg}$. $30 \%$ of patients in Group B presented with BP > 160/110 mmHg. In this study four patients had atypical presentation. In the study conducted by Pradeep MR et al, majority of patient had diastolic BP more than $110 \mathrm{mmHg}$ and in the study of Sunita $\mathrm{TH}$ et al, $68 \%$ of eclampsia patients had BP > 160/110 mmHg. ${ }^{24,28}$

The study conducted by Matter F et al, $16 \%$ of patient had no hypertension and Manjusha $\mathrm{S}$ et al in their study states that fits can occur without preceding either hypertension or proteinuria. ${ }^{26,28}$

In the study of Walker JJ et al, $20 \%$ of patient had convulsion unexpectedly, with normal blood pressure and without proteinuria. ${ }^{30}$

\section{Urine albumin}

In this study, 24\% patients in Group A and $14 \%$ in Group B had urine albumin $>3+$ which is comparable to $47.82 \%$ women had 4+ albuminuria in the study of Manjusha $\mathrm{S}$ et al. ${ }^{26}$

A total $8 \%$ patients in Group B presented with imminent symptoms even without proteinuria. Pradeep MR et al, studied eclamptic patient and in his study small proportion of group had no proteinuria. ${ }^{24}$

\section{Referral details}

In this study, $75 \%$ cases were referred. $6 \%$ of patients in Group A and $10 \%$ of patients in Group B were in-patients in this hospital developed imminent symptoms later.

\section{Mode of delivery}

In this study $87 \%$ of patients were delivered by caesarean section and $13 \%$ of patients were delivered by labour natural. LSCS plays major role in imminent eclampsia in order to prevent complications. Manjusha $\mathrm{S}$ et al, in their study had $56.25 \%$ of caesarean delivery and $45 \%$ in the study of Sunita TH et al. ${ }^{26,28}$

\section{Admission delivery interval}

In this study average admission delivery interval was 6 hours for imminent eclampsia. $76 \%$ cases were delivered within 12 hours in Group B in view of maternal and fetal condition, whereas $54 \%$ cases in Group A were delivered within 12 hours. In Group B, the incidence of AP eclampsia, Pulmonary edema, abruption were high. Hence emergency caesarean was done in view of maternal condition. Therefore, admission delivery interval was less in Group B due to increased maternal complication.

Early termination of pregnancy reduced the maternal mortality and morbidity.

\section{Convulsion delivery interval}

In this study, eclampsia patient who delivered within 6 hours had no adverse maternal outcome. Eclampsia patient who delivered in 7-12 hours of first convulsion had $7.5 \%$ of perinatal death and no adverse maternal outcome. Eclampsia patient who delivered in 13-24 hours of first convulsion had $10 \%$ of perinatal death. This study was comparable to the study by Rajasri G et al, Sunita $\mathrm{TH}$ et a, in which women delivered within 6 hours had least perinatal death and delivered $>24$ hours. had greater maternal and perinatal death. ${ }^{28,31}$ In study by Thoman et al $60 \%$ morbidity in women delivered $>48$ hours. $^{32}$ In study by Bhalerao A et al patient delivered 12-24 hours had $10.92 \%$ perinatal death and $1.82 \%$ maternal death. ${ }^{25}$ In eclampsia patient delivered > 24 hours had $16.38 \%$ perinatal death and $3.64 \%$ maternal death.

The onset of convulsion to delivery interval was very important to decide maternal and fetal outcome.

\section{Maternal complications}

\section{The maternal complications in this study}

- Incidence of imminent eclampsia - $1.2 \%$

- Incidence of eclampsia - $0.1 \%$

- Incidence of HELLP - $0.04 \%$

- Incidence of pulmonary edema $-0.06 \%$

- Incidence of PRES - $0.07 \%$

- Incidence of abruption $-0.14 \%$.

In the study of Singh S et al, 35\% of the eclamptic women have serious maternal complications includes placenta abruption - 10\%, neurological deficit - $7 \%$, pulmonary edema - 5\%, cardiopulmonary arrest $-4 \%$, acute renal failure $-4 \%$ and $1 \%$ maternal death. ${ }^{33}$

\section{Maternal mortality}

In Group A, maternal death was $2 \%$. One patient in Group A was died due to HELLP syndrome and DIC. In Group B, maternal death was 8\%. 4 cases in Group B were died due to refractory pulmonary edema. Maternal death was higher in group B when compared with Group A. In study by Bhalero A et al, maternal death was $5.45 \% .{ }^{25}$

\section{Birth weight}

In this study $40 \%$ Group B have good neonatal outcome with birth weight $>2.5 \mathrm{~kg}$. But in Group A, only $20 \%$ had weight $>2.5 \mathrm{~kg}$. 
A total $18 \%$ in Group B and 20\% in Group A babies have birth weight $<1.5 \mathrm{~kg}$. Manjusha $\mathrm{S}$ et al, and Rajasri $\mathrm{G}$ et al, in their study $21.7 \%$ and $22 \%$ of babies born to eclampsia patient were greater than $2.5 \mathrm{~kg}$ respectively and $78 \%$ of babies were between $1-2.5 \mathrm{~kg}^{26,32}$

\section{Perinatal outcome}

In the study by Bhalerao A et al, $41.82 \%$ of babies delivered by eclamptic patient were preterm, $27.27 \%$ were IUGR. ${ }^{25}$

Incidence of IUGR in Group A was 46\%, whereas in Group B 12\%. Prematurity is the commonest complication in babies of eclamptic mothers since termination of pregnancy is done irrespective of gestational age for definite cure.

\section{Perinatal mortality}

In this study, incidence of perinatal mortality was $2.2 \%$. whereas $25.45 \%$ in study by Bhalerao A et al and $19 \%$ in study by Sunita TH et al. ${ }^{25,28}$

\section{CONCLUSION}

By analysing the determinants of imminent eclampsia for better maternal and fetal outcome, the crucial factors are duration between imminent symptoms and timely administration of magnesium sulphate in nearby referring unit and decision for early termination of pregnancy at tertiary level hospitals.

In this study most dreadful complications were occurred in previously normotensive patients presented with high blood pressure and imminent symptoms.

Because known preeclampsia patients were aware of imminent symptoms and presented early to hospital. As compared to the developed countries the incidence of eclampsia is high in India. It has a great impact on maternal and fetal morbidity and mortality.

Proper antenatal care, early detection of pre-eclampsia, health education about imminent symptoms to patients and prompt management of pre-eclampsia are essential steps for prevention of eclampsia.

In current status on preventive aspect of eclampsia, atypical presentation should also be considered for which new screening and diagnostic tools has to be developed.

\section{ACKNOWLEDGMENTS}

Authors would like to thank dean, Theni Medical College and hospital, Theni, India for allowing us to do this study and utilizing the Institutional facilities. Authors would also like to thank all the medical and para-medical staffs who have helped us to complete this study. A special thanks to all the patients who willingly co-operated and participated in this study. Authors would also like to thank all the colleagues and friends who have been a constant source of encouragement to us.

Funding: No funding sources

Conflict of interest: None declared

Ethical approval: The study was approved by the Institutional Ethics Committee

\section{REFERENCES}

1. Uzan J, Carbonnel M, Piconne O, Asmar R, Ayoubi JM. Pre-eclampsia: pathophysiology, diagnosis, and management. Vasc Health Risk Manag. 2011;7:46774.

2. Jido TA, Yakasai IA. Pre-eclampsia: a review of evidence. Ann Afr Med. 2013;12(2):75-85.

3. Park JH, Chung D, Cho HY, Kim YH, Son GY, Park $\mathrm{YW}$, et al. Random urine protein/creatinine ratio readily predicts proteinuria in preeclampsia. Obstet Gynecol Sci. 2013;56(1):8-14.

4. Duley L. The global impact of pre-eclampsia and eclampsia. Semin Perinatol. 2009;33(3):130-7.

5. Swati S, Ekele BA, Shehu CE, Nwobodo EI. Hypertensive disorders in pregnancy among pregnant women in a Nigerian Teaching Hospital. Nig Med J. 2014;55(5):384-8.

6. World Health Organization. Trends in Maternal Mortality: 1990 to 2008. 2010. Available at: https://www.who.int/reproductivehealth/publication/ monitoring/9789241500265/en/. Accessed on $14^{\text {th }}$ August 2018.

7. Chan P, Brown M, Simpson JM, Davis G. Proteinuria in pre-eclampsia: how much matters? Int J Obstet Gynaecol. 2005;112:280-5.

8. Waugh JJS, Smith MC. Hypertensive Disorders. In: Edmond DK (ed). Dewhurst's Textbook of Obstetrics and Gynaecology. $8^{\text {th }}$ ed. John Wiley and Sons, Ltd.; 2012:101-110.

9. Cunningham FG, Leveno KJ, Bloom SL, Spong CY, Dashe JS, Hoffman BL, et al. Hypertensive disorders. Williams Obstetrics. $24^{\text {th }}$ ed. USA: McGraw-Hill companies; 2014:728-779.

10. Mustapha R, Ahmed S, Gupta A, Venuto R. A Comprehensive review of hypertension in pregnancy. J Preg. 2012;10(5):91-109.

11. Sabitha K, Gopal BV, Raj KG, Rafi MD, Sudhakar T, Ramadevi C, et al. Preeclampsia: its effect on renal, cardiovascular, hepatic and thyroid functions a review. Am J Clin Med Res. 2014;2(6):111-3.

12. The American College of Obstetricians and Gynecologists. Diagnosis and Management of Preeclampsia and Eclampsia. ACOG Practice Bulletin 33, 2002. Available at: journals. Iww.com/green journal/Full text/2002/01000 /ACOG_Practice_Bulletin_No_. Accessed on $13^{\text {th }}$ August 2018.

13. von Dadelszen P, Magee LA, Devarakonda RM, Hamilton T, Ainsworth LM, Yin R, et al. The prediction of adverse maternal outcomes in 
preeclampsia. J Obstet Gynaecol Can. 2004;26:8719.

14. Nevo O, Soleymanlou $\mathrm{N}$, Wu Y. Increased expression of sFlt-1 in in-vivo and in-vitro models of human placental hypoxia is mediated by HIF-1. Am J Physiol. 2006;291(4):1085-93.

15. Levine RJ, Lam C, Qian C. Soluble endoglin and other circulating antiangiogenic factors in preeclampsia. N Engl J Med. 2006;355(10):9921005.

16. Tranquilli AL, Brown MA. Zeeman GG, Dekker G, Sibai BM. The definition of severe and early-onset preeclampsia. Statements from the International Society for the Study of Hypertension in Pregnancy (ISSHP). Int $\mathrm{J}$ women Cardiovascular Health. 2013;3:44-7.

17. National Collaborating Centre for Women's and Children's Health. Hypertension in pregnancy the management of hypertensive disorders during pregnancy. NICE Clinical Guideline August 2010. Available at: https://www.nice.org.uk/guidance/cg107. Accessed on $26^{\text {th }}$ August 2018.

18. Confidential Enquiry into Maternal and Child Health. Saving Mothers' Lives: Reviewing maternal deaths to make motherhood safer 2003-2005: The Seventh Report of the Confidential Enquiries into Maternal Deaths in the United Kingdom. Available at: https://www.hqip.org.uk/resource/cmaceandcemach-reports/. Accessed on $25^{\text {th }}$ August 2018.

19. Ekine AA, Jeremiah I, Harry TC, West OL. Factors influencing the prevalence of Preeclampsia eclampsia in booked and unbooked patients: 3 years retrospective study in NDUTH, Okolobiri. World J Med Med Sci. 2015;3(1):1-14.

20. Agwu UM, Ifebunandu N, Obuna AJ, Nworie EO, Nwopko SO, Umeora OUJ. Prevalence of medical disorders in pregnancy in Ebonyi State university teaching hospital. J Basic Clin Reprod Sci. 2013;2(1):22-6.

21. Abubakar A, Abdullahi RA, Jibril HZ, Dauda MN, Poopola MA. Maternal ethnicity and severity of preeclampsia in Northern Nigeria. Asian J Med Sci. 2009; 1(3):104-7.

22. Ebeigbe PN, Aziken ME. Early onset pregnancy induced hypertension/eclampsia in Benin City. Nig J Clin Pract. 2010;13:4.
23. Ugwu E, Dim CC, Okonkwo CD, Nwankwo TO. Maternal and perinatal outcome of severe preeclampsia in Enugu, Nigeria after introduction of Magnesium sulfate. Niger $J$ Clin Pract. 2011;14(4):418-21.

24. Leveno KJ, Alexander JM, McIntire DD. Does magnesium sulfate given for prevention of eclampsia affect the outcome of labor? Am J Obstet Gynecol. 1998;178:707.

25. Pradeep MR, Shivanna L. Retrospective study of eclampsia in a teaching Hospital. Inter $\mathbf{J}$ Recent Trends Sci Technol. 2013;8(3):171-3.

26. Bhalerao A. Eclampsia: maternal and fetal outcome. J South Asian Feder Obstet Gynaecol. 2013;5(1):1921.

27. Manjusha S, Vandana N, Goutham R, Sneha M, Atmaram PP. Eclampsia: a retrospective study in a tertiary care centre. Indian J Pharma Pract. 2013;6:1.

28. Knight M. Eclampsia in the United Kingdom 2005. Inter J Obstet Gynaecol. 2007;114(9):1072-8.

29. Sunita TH, Desai RM. Eclampsia in a teaching hospital: incidence, clinical profile and response to magnesium sulphate by Zuspan's regimen. J Dent Med Sci. 2013;4(2):1-5.

30. Zwart JJ, Richters A, Öry F. Eclampsia in the Netherlands. Obstet Gynecol. 2008;112:820.

31. Walker JJ. Severe pre-eclampsia and eclampsia. Bailliere's Clin Obstet Gynaecol. 2000;14(1):57-71.

32. Yaliwal RG, Jaju PB, Vanishree M. Eclampsia and perinatal outcome: a retrospective study in a teaching hospital. J Clin Diagnos Res. 2011;5(5):1056-9.

33. Jofy TJ. Are we increasing serious maternal morbidity by postponing termination of pregnancy in severe pre-eclampsia and eclampsia. J Obstet Gynecol. 2004;24(7):765-8.

34. Cunningham DS, Christie TI. Effect of HELLP syn on maternal immune function. J Reprod Med. 1993;38(6):459-64.

Cite this article as: Raji C, Suba S. Comparative study: normotensive and preeclampsia mother presenting with imminent symptoms of eclampsia in third trimester of pregnancy. Int J Reprod Contracept Obstet Gynecol 2020;9:1654-63. 